\title{
The Effect of Creative Drama on Student Achievement in The Course of Information Technologies ${ }^{1}$
}

\author{
Müzeyyen Bulut Özek \\ Correspondence: Müzeyyen Bulut Özek, Education Faculty, Firat University, Turkey
}

$\begin{array}{lcc}\text { Received: February 14, } 2016 & \text { Accepted: February 27, } 2016 \quad \text { Online Published: March 22, } 2016 \\ \text { doi:10.11114/jets.v4i6.1370 } & \text { URL: http://dx.doi.org/10.11114/jets.v4i6.1370 }\end{array}$

\begin{abstract}
The purpose of this study is to determine the effect of creative drama on student achievement in the Information Technologies course. The study was carried out for the unit "Tomorrow's Technology" which is the first unit of Information Technologies course. For this study, 89 sixth grade students were selected from primary school in academic year of 2012-2013. The pre- and post-test control group research model was used in this study. The experimental and control group randomly formed. Students were randomized to three groups: experimental 1 group (28 students), experimental 2 group (30 students) and control group (31 students). In experimental 1 group, course were lectured using creative drama method. In experimental 2 group, course were lectured with computer based, the course were lectured by using only the Information Technologies course curriculum in control group. An achievement test used to collect data were developed by the researcher. According to the result of the study, it was seen that using Creative Drama in Information Technologies Course created a positive effect on students' achievement. Considering these result, some suggestions were presented.
\end{abstract}

Keywords: creative drama, achievement, information technologies course

\section{Introduction}

Education is the sum of all activities that initially assists the individuals to know themselves, then prepare them for the future to establish a safe ground for living in harmony with the others. By virtue of its characteristics such as aiding a transformation in the emotional and intellectual lives of people as well as guiding and controlling individuals' actions and conducts, education stands out as a critically substantial phenomenon (Çağlayan, 2005). Thereby any individual is expected to play active role in this major phenomenon. Active involvement in education necessitates a person's full involvement with learning process by utilizing all his/her senses. People do not forget the things learnt through experience and they can transfer their learning to previously grasped data (Karadağ \& Çalışkan, 2008). One of the methods enabling active involvement of people with learning and teaching is creative drama.

Creative drama, in its broadest sense, creats animations with a group on the basis of experiences and accumulations of group members by making use of techniques such as improvisation and role-play in any given subject. San (1989), who is one of the leaders of creative drama in Turkey, defines creative drama such; "With no pre-written text, actions and impromptu animations that the participants create on the basis of their own creative discoveries, authentic ideas, subjective memoirs and previous knowledge." According to Adiguzel (2006a), creative drama in education animates any subject by using improvisation, role playing and the life experiences of a group.

Çoruh (1950) asserts that dramatic shows and theatrical actions \& behaviors that are transposed to meet the spiritual and physical changes children and youngsters demonstrate at various ages, shall provide assistance in their learning process. Çilenti (1979) similarly argues that by utilizing such activities:

- Complex situations become better understandable.

- Too big or too small events exceeding the perceptive limits of sensory organs can be better perceived and grasped.

- Events that are, due to time and space limits, unreachable can be examined more easily.

\footnotetext{
1 The results of this research was presented at " $1{ }^{\text {st }}$ International Eurasian Educational Research Congress" on 24-26 April, 2014. Istanbul, Turkey.
} 
- The designed abstract and theoretical events and objects can be better understood.

- Students' communication skills like attention, speech, listening, comprehension, perception and interpretation can be refined.

- Creativity skills of students are improved.

- It helps to heal introvert, shy and self demeaning students.

- The habit to work collaboratively is instilled.

The gravity of creative drama has been enhancing each day. Currently creative drama activities have been conducted in all stages of education ranging from pre-school period to undergraduate and graduate studies. In primary education level, creative drama activities are available in science, mathematics and social sciences courses (Çokadar \& Yılmaz, 2010; Çam, Özkan, \& Avinç, 2009; Gencel, 2009; Oğur \& Kılıç 2005; Sarıçoban 2004; Selmanoğlu, 2009; Şengün, \& İskenderoğlu, 2010; Ruso, \& Topdal, 2013; Türkkuşu, 2008). Nonetheless there exist almost no creative drama activities in Information Technologies (IT) course curriculum. However in the vision of Information Technologies course curriculum developed as of 2007-2008 by Ministry of National Education, Head Council of Education and Morality in Turkey, it has been underlined that raising individuals with high-level of IT education is a requirement to keep up with modern age. It has also been emphasized that to ensure operating effectively in work environments that all change in line with technological developments, there are certain skills required such as ability to work in a team, refined communication skills, ability to manage unforeseen situations, think critically and make proper decisions. To gain such capabilities, utilizing creative drama method shall be the most effective aid.

Since IT is basically a domain that can be learnt best through practice and experience, in IT course program, starting from basic operations and concepts it is aimed to lead students to find project-based solutions for real-life problems by working in groups. Creative drama is, as emphasized by San (2003) and Adigüzel (2006b), a cluster activity manipulating techniques such as impromptu, role play, theater or drama; hence without a group, creative drama cannot be performed. In that respect as well, creative drama can be viewed as an applicable method for IT course.

The main objective of IT course is to ensure that students can provide solutions against unexpected situations and applications and adapt to new conditions with minimum discomfort. Drama practices, by means of benefits provided, play enormous role in the participation of students into society as fully equipped individuals. Such individuals can be motivated into their works, cooperate with their workmates to seek and produce joint solutions to the problems. They generate novel ideas and adapt to different situations easily. Such acquisitions of drama likewise serve to the key objective of IT course.

Aside from such positive features of IT, it also exhibits certain negative impacts that can be listed as increasing amounts of internet overuse and computer game addiction which collectively undermine the user's socialization skills. Conducted researches (Şendağ \& Odabaş1, 2007) have unveiled that people who spend considerable amount of time on computer demonstrate social adaptation problems. As the time spent on computer increases the individual exhibits weaker social adaptation skills. In reality sixth grade (12-13 years old) group students composing the research population belong to a social stage in which they should be willing to spend time with peers rather than parents, hungry for new insights, full of life and zeal. For the students in this age group as well, socialization is a learning process in which they grasp an idea about the role and demands that the society expects them to possess (Akfirat, 2004; Bolton, 1985).

The aims of using creative drama activities in education are not restricted only developing social and individual skills. The effects of creative drama activities on achievement of students also have been studied by many researchers from various fields. In those studies creative drama activities are found to increase the students' achievement on geography (Köseoğlu \& Ünlü, 2006), humanities (Karadağ, Korkmaz \& Çalışkan, 2007), science and technology (Oğur \& Kılıç, 2005; Doğru, Yilmaz, Kalay \& Gençosman, 2010) and Turkish language (Şimşek, Topal, Maden \& Şahin, 2010) courses. In order to reveal the students' inner potential teachers have to develop new methods and approaches. With this important direction, this study has probed into the achievement effects of creative drama method which shall, in the teaching of "Tomorrow's Technology" which is a unit of IT of primary school sixth grade, by boosting student's self esteem and confidence, enable their socialization and develop their communication \& problem solving skills.

\section{Methodology}

\subsection{Research Design}

In present study, a pre-test/post-test experimental design with control group (Karasar, 2005) was utilized to uncover the effects of methods such as computer-based learning, creative drama and IT course curriculums on students' achievement level. 


\subsection{Research Sample}

Since there was no possibility to make a generalization of universe in this research, a sample research group was used. Sönmez (2005) emphasizes that researchers may prefer universe-sample selection in descriptive studies, while this does not apply to experimental studies. Research group consisted of 89 sixth grade students randomly were chosen from primary school in academic year of 2012-2013. Socio-demographic structures of the students in the classes and the achievement levels were similar. Information technologies teacher and students were volunteered to participate in the study.

\subsection{Treatment}

In the control group composed of 31 students, teaching of "Tomorrow's Technology" was conducted with IT course curriculum. For experimental 2 group, courses was given to 30 students in Information Technologies classroom. A computer was assigned to each student. Students utilized prepared material, worked individually and received guidance from teacher when they need help. In experimental 1 group, creative drama method was practiced with 28 students.

In this research, the program integrated with creative drama utilized in experimental 1 group was prepared together with the researcher and a certified drama trainer approved by the Ministry of National Education in accordance with the acquisitions in coursebook. In experimental 1, experimental 2 and control group courses were lectured within the same weeks and days. As the learning acquisitions within the scope of research were examined it was structured such: "It draws conclusions on the potential impact of IT in the future and its potential development."

\subsection{Example of a Drama Lesson}

In planning creative drama actions suggested creative drama components like; preparation, play, improvisation, relaxation; drama techniques, dramatic moment, pretending, teacher \& student roles, group works and playlike processes have been accounted. Below is a practiced drama activity.

\section{Sample}

Objectives: Familiarization with modern communication tools

Montage Room: Information Technologies classroom

Contents: Modern communication tools are introduced. Plays are prepared.

Role of the students: Any given communication tool

Role of the teacher: Drama Leader

\section{Preparation}

Warm-up: Music playing on the background, students walk freely around class.

Instructions:

$>$ Walk around each corner of the classroom pacing with the rhythm of music. Hear the sound only.

$>$ Freeze when the music stops, use any given communication tool (animation). Share your feelings, what you have touched and done.

$>$ Select a different tool each time.

$>$ Now freeze wherever you are once the music stops. "Which communication tool are you now?"

Play Instructions:

$>$ Now let everyone imagine there is a tool in front of you.

$>$ Inspect the tool in front of you. Who uses this tool? Why has this tool been developed? What qualities do you exhibit? How further can you be developed? and similar open-ended questions enable the students to contemplate more.

$>$ Who would like to share his/her ideas with me?

$>$ Would you like to share with me any interesting experience you had earlier?

\section{Improvisation:}

$>$ Those with the same tools gather in the same groups.

$>$ These groups create a scene with these tools.

$>$ Group questions: For what purpose this communication tool is used? Why do these people communicate? What do they feel when they communicate? are some of the warm-up questions. 
$>$ The groups are monitored individually.

Relaxation:

$>$ The feelings of students after this cooperative work are communicated.

$>$ Walking while background music playing.

$>$ Muscle relaxation movements.

\subsection{Data Collection}

In present study data were collected via achievement test. The first format of the achievement test consisting of 23 multiple-choice questions were prepared. To conduct validity check of achievement test, assistance was taken from the Turkish teacher and IT teacher in the same school and an educational sciences specialist employed in Frrat University. In order to evaluate the validity and reliability of the achievement test, achievement test was delivered as a pilot study to 43 sixth grade students who exhibit similar features with research group and who succeeded previously in this course. 3 questions in the test were excluded from the test since they exhibited low distinctiveness in item analysis. Upon item analysis three questions were excluded and the final format included 20 multiple-choice questions. In order to calculate the reliability of the test, the Kuder Richardson-20 (KR-20) value was calculated. For the final format of achievement test, reliability coefficient was found to be 0.70 .

\subsection{Data Analysis}

Specify the research design in the Method section. Were subjects placed into conditions that were manipulated, or were they observed naturalistically? If multiple conditions were created, how were participants assigned to conditions, through random assignment or some other selection mechanism? Was the study conducted as a between-subjects or a within-subject design?

\section{Findings}

ANOVA was performed in order to determine whether statistically significant differences existed between the groups (experimental 1, experimental 2, control) with respect to the pre-information. Results were illustrated in Table 1. According to Table 1, no significant difference existed among the pre-test scores of the groups $(p=0.257)$. This finding shows that groups are homogeneous with respect to pre-information.

Table 1. Results of one way ANOVA on pre-test Scores

\begin{tabular}{llllll}
\hline & Sum of Squares & Sd & Mean Square & F & $\mathrm{p}$ \\
\hline Between Groups & 357.371 & 2 & 178.686 & 1.381 & .257 \\
Within Groups & 11129.101 & 86 & 129.408 & & \\
Total & 11486.472 & 88 & & &
\end{tabular}

For the purpose of reveal whether significant differences exit between pre-test and post-test scores of groups, paired sample t-test was conducted. Arithmetic means, standard deviation and results of t-test computed with respect to pre-test and post-test scores of groups were illustrated in Table 2.

Table 2. Results of paired sample t-test on pre-test and post-test Scores for Control Group

\begin{tabular}{lllllll}
\hline Groups & $\mathrm{N}$ & $\overline{\boldsymbol{X}}$ & $\mathrm{S}$ & $\mathrm{Sd}$ & $\mathrm{t}$ & $\mathrm{P}$ \\
\hline Control Group pre-test & 31 & 32.16 & 9.34 & \multirow{2}{*}{30} & \multirow{2}{*}{-13.27} & \multirow{2}{*}{.000} \\
Control Group post-test & 31 & 40.9 & 8.56 & & & \\
\hline Experimental 2 Group pre-test & 30 & 36.8 & 11.59 & \multirow{2}{*}{29} & \multirow{2}{*}{-16.79} & \multirow{2}{*}{.000} \\
Experimental 2 Group post-test & 30 & 51.17 & 10.06 & & & \\
\hline Experimental 1 Group pre-test & 28 & 35.68 & 13.08 & \multirow{2}{*}{27} & \multirow{2}{*}{-14.23} & .000 \\
Experimental 1 Group post-test & 28 & 66.93 & 12.81 & & &
\end{tabular}

As shown in Table 2, a significant difference was found between the pre-test and post-test scores of groups. The post-test arithmetic mean was found 40.9 while the pre-test arithmetic mean of control group was 32.16. Similarly, while the pre-test academic mean of the students' in experimental 2 group was 36.8, post-test arithmetic mean calculated 51.17. The arithmetic mean for the experimental 1 group was found 35.68 for the pre-test and 66.93 for the post-test. Paired sample t-test results revealed that each group improved in regard to their post-test scores.In other words, these three method was effective on learning. To reveal the difference of the main effect of the methods between groups, 
ANCOVA was conducted with means of the post-test scores as the dependent variables and the pre-test scores as the covariates.

For the purpose of finding whether the differences between the arithmetic means of groups in the post-test were statistically significant, analysis of covariance was conducted. The test results of ANCOVA were illustrated in Table 3.

Table 3. Results of ANCOVA on post-test scores with pre-test scores as the covariates

\begin{tabular}{llllll}
\hline Source of Variance & Sum of Squares & Sd & $\begin{array}{l}\text { Mean } \\
\text { Square }\end{array}$ & F & $\mathrm{p}$ \\
\hline Pre-test & 5756.21 & 1 & 5756.21 & 128.469 & .000 \\
Group & 8395.10 & 2 & 4197.55 & 93.68 & .000 \\
Error & 3808.52 & 85 & 44.81 & & \\
Total & 265395 & 89 & & & \\
\hline
\end{tabular}

According to Table 3, when the pre-test scores of the groups were controlled there appears a statistically significant difference between the post-test score of groups $(\mathrm{f} 2.85=93.68, \mathrm{p}<.001)$. More specifically, the corrected mean post-test score of the experimental 1 group $(X=64.13)$ was higher than experimental 2 group $(X=50.57)$ and control group $(X=43.13)$. In that case it was concluded that creative drama method has significant and positive effects on the student achievement.

\section{Discussions and Suggestions}

In this study conducted to explore the effect of creative drama method on students' achievement level in teaching "Tomorrow's Technology" which is a unit of IT primary school sixth grade it was designated that there is significance difference in favor of creative drama method. The results obtained from the study are positive. This finding points out that, creative drama method is, compared to both computer-based learning method and other methods present in IT course curriculum, a further effective method on a set of learning experiences. The key explanation is that once students take active role in learning process permanent learning is possible which echoes the findings obtained in (Çam et al., 2009; Timuçin, 2009; Adıgüzel \& Timuçin, 2010; Başçı \& Gündoğdu, 2011; Atalay \& Şahin, 2012) research.

In experimental 1 group where creative drama is employed it was detected that compared to experimental 2 and control group, students interact with each other more intensely, listen to one another more diligently, act in better harmony, exhibit more joyful and enthusiastic behavior. In the studies of Erbay \& Doğru (2010), as in parallel with this study, it was found that creative drama education had a significant positive effect on the social communication skills of the subject.

To create a further effective learning in primary education IT course curriculum, creative drama activities, which provide considerable benefits, should be integrated. This study can be recreated for different issues in IT course as well as for different grade levels. In 2013 dated IT and Software coursebook; while teaching Importance of Information Technologies on Daily Life, Social and Cultural Benefits, Privacy and Security Dimensions, Ethical and Social Values issues, employing creative drama as a teaching method shall provide outstanding benefits. Particularly in the teaching of programming and algorithm creation which are among the IT course issues students hardly grasp, employing creative drama shall enable to receive better learning outcomes.

Drama is a compulsory subject in primary school education, pre-school education and English language education departments of Faculty of Education. Replicating these departments, in the undergraduate studies of Computer Education and Instructional Technologies (CEIT) Department and other departments in Faculties of Education "Creative Drama and its Applications" should be integrated to the curriculum as a compulsory or elective subject.

For future studies, the advantages of creative drama in education can be explained to teachers through various seminars and work-shop (Lee, Cawthon \& Dawson, 2013). In order to widespread the use of creative drama method in different courses, as suggested by Sungurtekin, Sezer, Kahraman, \& Sadioğlu (2009), in service training seminars should be organized not only to class teachers but also to branch teachers. Hence it shall be feasible for teachers from different branches to experience creative drama collectively. During their own classes, they could give place to creative drama activities for the purposes of enhancing the efficiency and quality of education.

It matters vitally that schools contain all the required course materials so that students can receive optimum efficiency while learning a particular topic. As is the case in all the other courses, there has to be a suitable working environment to meet creative drama activities with the key objectives. To achieve that mission, as suggested by Başçı \& Gündoğdu (2011), drama rooms in schools must be built to perform creative drama activities and required tools and materials should be catered. 
Further research can also be made to determine the views of the teachers who have used creative drama in IT course on the sufficiency of the method and to remove the problems that are likely to occur in practice. However it is suggested that different research studies should be done related to determining the effects of Creative Drama applications on students' gender, parents, socio-economic conditions which they lived. Also their effects on communication, social skills, empathy, self sufficiency, problem behavior and promoting language development should also be investigated. The number of similar studies should be increased to make a contribution to the field.

\section{References}

Adıgüzel, H. Ö. (2006a). Ĕgitimde Yeni Bir Yöntem Ve Disiplin: Yaratıcı Drama. Adıgüzel H. Ö. (Ed), Yaratıcı Drama 1985-1998 Yazılar, Genişletilmiş 2. Baskı. 203-222 Ankara: Natürel.

Adıgüzel, H. Ö. (2006b). Yaratıcı Drama Kavramı, Bileşenleri Ve Aşamaları, Yaratıcı Drama Dergisi, 1(1), 17-31.

Adıgüzel, H. Ö., \& Timuçin, E. (2010). The effect of creative drama on student achievement in the instruction of some development and learning theories. Procedia Social and Behavioral Sciences, 9, 1741-1746. http://dx.doi:10.1016/j.sbspro.2010.12.393

Akfirat, F. Ö. (2004). Yaratıcı Dramanın İşitme Engellilerin Sosyal Becerilerinin Gelişimine Etkisi. [The method of creative drama on hearing impaired students' social skills]. Ankara Üniversitesi Eğitim Bilimleri Fakültesi Özel Eğitim Dergisi, 5(1), 9-22.

Atalay, O., \& Sahin, S. (2012). İlköğretim 5.Sınıf bilişim teknolojileri dersinin öğretiminde drama öğretim yönteminin öğrenci başarısına etkisi. Eğitim Teknolojisi Kuram ve Uygulama, 2(2), 1-9.

Başçı, Z., \& Gündoğdu K. (2011). Öğretmen Adaylarının Drama Dersine İlişkin Tutumları ve Görüşleri: Atatürk Üniversitesi Örneği. İlkögretim Online, 10(2), 454-467.

Bolton, G. (1985). Changes in Thinking About Drama in Education. Theory into Practice, 24(3), 151-157.

Çağlayan, A. (2005). Anne-Baba ve Eğitimcilere Aspirin Öğütler, İstanbul: Bilge Matbaacılık.

Çam, F., Özkan, E., \& Avinç, İ. (2009). Fen ve Teknoloji Dersinde Drama Yönteminin Akademik Başarı ve Derse Karşı İlgi Açısından Karşılaştırmalı Olarak İncelenmesi: Köy ve Merkez Okulları Örneği GÜ, Gazi Eğitim Fakültesi Dergisi, 29(2), 459-483.

Çilenti, K. (1979). Eğitim Teknolojisi. Ankara: Kadığlu Matbaası.

Çokadar, H., \& Yılmaz, G. C. (2010). Teaching ecosystems and matter cycles with creative drama activities. Journal of Science Education and Technology, 19(1), 80-89.

Çoruh, S. (1950). Okullarda dramatizasyon, Öğretmen Dergisi 2.Bask1, İstanbul: Işı1 Matbaası.

Doğru, M., Yilmaz, T. T., Kalay, A., \& Gençosman, T. (2010). Effect of creative drama method in science and technology course on the attitudes of primary school fifth grade students towards the course and on their achievements. Practice and Theory in Systems of Education, 5(2), 133-144.

Erbay, F., \& Doğru, S. S. Y. (2010). The effectiveness of creative drama education on the teaching of social communication skills in mainstreamed students. Procedia Social and Behavioral Sciences, 2, 4475-4479. http://dx.doi:10.1016/j.sbspro.2010.03.714

Gencel, İ. E. (2009). The Effects of Creative Drama Technique on Achievement and Attitude Toward Social Studies Course, Çă̆daş Ĕ̆itim Dergisi, 34(360), 5-13.

Karadağ, E., Korkmaz, T., \& Çalışkan, N. (2007). The evaluation of the effectiveness of drama method in teaching of social sciences according to cognitive domain. Ahi Evran Üniversitesi Kırşehir Eğitim Fakültesi Dergisi, 8(1), 179-195.

Karadağ, E., \& Çalışkan, N. (2008). Kuramdan Uygulamaya İlköğretimde Drama. Ankara: Anı.

Karasar, N. (2005). Bilimsel Araştırma Yöntemi, 14. Baskı, Ankara: Nobel Yayın Dağıtım.

Köseoğlu, İ., \& Ünlü, M. (2006). Coğrafya dersinde drama tekniğinin öğrenci başarısına etkisi. Marmara Coğrafya Dergisi, 13, 125-132.

Lee, B., Cawthon, S., \& Dawson, K. (2013). Elementary and secondary teacher self-efficacy for teaching and pedagogical conceptual change in a drama-based professional development program. Teaching and Teacher Education, 30, 84-98. http://dx.doi:10.1016/j.tate.2012.10.010

Milli, E. B. (1999). İköğretim Drama 1 [Drama in Primary School 1]. (For Teachers). Devlet Kitapları. Ankara.

Milli, E. B. (2007). Mesleki Eğitim Ve Öğretim Sisteminin Güçlendirilmesi Projesi Çocuk Gelişimi Ve Eğitimi Drama 
Uygulamaları. http:// megep.meb.gov.tr/mte_program_modul/moduller_pdf/Drama\%20Çalışmaları.pdf Accessed 04 January 2014.

Oğur, B., \& Kılıç, G. (2005). The effect of drama integrations into science courses on student science achievement. Eurosian Journal of Educational Research, 20, 178-188.

Ruso, L., \& Topdal, E. B. (2013). The Use of Museums for Educational Purposes Using Drama Method. Procedia Social and Behavioral Sciences, 141, 628-632. http://dx. doi:10.1016/j.sbspro.2014.05.110

San, İ. (1989). Eğitimde yaratıcı drama. Ö. Adıgüzel, (Ed.), Yaratıcı drama içinde (57-68). Ankara: Naturel.

San, İ. (2003). Drama ve Öğretim Bilgisi. 5.Uluslararası Eğitimde Drama. Ankara: Naturel.

Sarıçoban, A. (2004). Using drama in teaching Turkish as a foreign language. Eurasian Journal of Educational Research, 4(14), 13-32.

Selmanoğlu, E. (2009). The Effect of Creative Drama on The Achievement of the Students of Elementary School 5th Grade Turkish Course, Unpublished Master's Thesis, University of Abant İzzet Baysal, Bolu, Turkey.

Sungurtekin, Ş., Sezer, G. O., Kahraman, P. B., \& Sadioğlu, Ö. (2009). The views of pre-service teachers about creative drama: A study according to gender. İlkögretim Online, 8(3).

Şendağ, S., \& Odabaşı, F. (2007, May). Internet Addiction: Effects on Psychosocial development of children. The Proceedings of $7^{\text {th }}$ International Educational Technology Conference, Near East University, North Cyprus.

Şengün, Y., \& İskenderoğlu T. (2010). A review of creative drama studies in math education: aim, data collection, data analyses, sample and conclusions of studies. Procedia Social and Behavioral Sciences, 9, 1214-1219.

Şimşek, T., Topal, Y., Maden, S., \& Şahin, A. (2010). İlköğretim II. Kademe Türkçe Dersinde Zarf (Belirteç) Konusunun Drama Yöntemi Kullanilarak Öğretimi. National Education, 106.

Sönmez, V. (2005). Bilimsel araştırmalarda yapılan yanlışlıklar. Eğitim Araştırmaları Dergisi., 18, 150-170.

Talim ve Terbiye Kurulu Başkanlığı (2006). İlköğretim bilgisayar dersi (1-8. sınıflar) öğretim programı. http://ttkb.meb.gov.tr/www/ogretim-programlari/icerik/72. Accessed 04 March 2015

Timuçin, E. (2009). İlköğretim 4. Sinıf Bilişim Teknolojileri Dersinde Yaratıcı Drama Uygulaması. 3. Uluslararası Bilgisayar ve Öğretim Teknolojileri Eğitimi Sempozyumu, Karadeniz Teknik Üniversitesi, Trabzon.

Türkkuşu, B. (2008). Drama method practice to the effects of student success with in division topics, Unpublished Master's Thesis, University of Kafkas, Kars, Turkey.

This work is licensed under a Creative Commons Attribution 3.0 License. 